\title{
ANTINOMIES OF RESEARCH METHODS IN SOCIAL SCIENCES: METHODENSTREIT
}

\author{
UDC 303.01
}

\author{
Jelena Božilović \\ University of Niš, Faculty of Philosophy, Department of Sociology, Niš, Serbia
}

\begin{abstract}
The central issue of this paper is the so-called dispute over methods (Methodenstreit), which is based on the essential difference between natural and social phenomena. Methodological problems in sociology are related to the determination of its subject matter, and the history of the science has showed that these problems have represented the main point of disagreement between theoreticians. The debates on the issues of natural and social phenomena and, thus related, manners of their examination, began as early as in the times of ancient philosophy - starting with Aristotle, and continued through the so-called Galilean tradition that would find its peak in the positivist movement and the historistic school as its opposition. The paper draws attention to the theoreticalmethodological positions of both sides in this dispute, the reaffirmation of hermeneutics, as well as the ideological background. Furthermore, certain opinions that formed through the integration of these two methodological approaches are also discussed here. The time of the Methodenstreit is the time when sociology was constituted, thus the concluding remarks emphasize the importance of this dispute for the constitution of sociology as a science, with a particular reflection on the influence of historism on German sociologists.
\end{abstract}

Key words: positivism, historism, hermeneutics, romanticism, sociology.

\section{INTRODUCTION}

When talking about the Methodenstreit (German for the dispute over methods), one should emphasize that this is a debate that has no end nor any final resolution. It began in the $19^{\text {th }}$ century, a time when social sciences constituted their subject matter and methodology, and it has continued throughout the entire $20^{\text {th }}$ century to date. If one were to search for the deeper roots of this dispute, they could be found in ancient times. Dealing with politics as the science of the state, Aristotle wrote about this science being specific in that it was not possible to establish laws within it with the same accuracy as in mathematics, and that one should be satisfied with merely describing events. If it were at all possible to find everlasting laws

Received April 5, 2017 / Accepted June 16, 2017

Corresponding author: Jelena Božilović

University of Niš, Faculty of Philosophy, Ćirila i Metodija 2, 18000 Niš, Serbia

E-mail: jelena.božilovic@ filfak.ni.ac.rs 
in politics, every state would be happy, even if it had an average ruler who would only follow the rules of the science of the state. Since this is not the case, the ruler has to be wise so as to make decisions for the general welfare, which will lead a state to the fulfilment of its purpose - a happy life. Contrary to the Aristotelian tradition was the Galilean tradition that appeared many centuries later. It is related to the period of the Late Renaissance and Baroque (the beginning of the $17^{\text {th }}$ century), that is, the time of the rise of natural sciences and scientific discoveries. While the Galilean theoretical preoccupation endeavours to explain and predict, the Aristotelian strives for the understanding of phenomena, since it believes that human activity cannot be reduced exclusively to the natural process, even though it is partially determined by nature. The Galilean tradition seeks the cause, while the Aristotelian seeks the purpose, which makes it teleological (von Wright 1975, 56).

The empiricism and rationalism of the modern period, faith in progress, and the omnipotence of science and technology left a profound impression on modern era social scientists, particularly those of the $19^{\text {th }}$ century, who used the scientific discoveries of natural sciences and mathematics as role models for the establishment of social sciences. This was, above all, the case with positivism and Auguste Comte. In order to harmonize natural and social sciences, positivists started from the tenet of methodological monism (later adopted by Popper), as a standpoint on the unity of the scientific method of all sciences. Their perspective rested on the belief that causal explanations and laws could be observed in social movements as well. However, when Comte speaks of lawfulness, this does not assume determinism, but merely the regularity that reoccurs in the relationship between two phenomena. That is why his understanding of a law is phenomenalistic (Milic 1978, 84). Furthermore, what Comte's philosophy of society was significantly marked by was faith in the historical progress of the society. Comte speaks of different stages of this development, with the era in which he lived designated as the epoch of the domination of the scientific and positive spirit, that had begun in the times of Galileo. In accordance with such a belief, Comte assigned a task to himself to establish the subject matter and method of the new science about society, which would thus become successfully emancipated from all philosophical and metaphysical speculations surrounding it. The critique was primarily directed towards the dualism found as early as in Plato's philosophy, and which dealt with the separation of the essence from the phenomenological. Comte believed that only the domain of the experiential and the observable could be the subject matter of social scientific research, while general laws were out of the reach of the scientific spirit, and that things should remain that way. It is interesting to note that, despite his sincere insistence on constructing a single "positive scientific" system, Comte's theoretical position retained a speculative character, with the elements of pure philosophical contemplation (Milić 1978, 96).

Similarly to all other movements, positivism is also not monolithic, but contains numerous variations within itself. Its other founding fathers, such as John Stuart Mill and Émile Durkheim, diverged from Comte's viewpoint, creating their own original positivistic concepts. Not attempting to delve deeper into the ideas of these authors here, let us just point out that Mill significantly influenced the continuation of the dispute over methods in the $20^{\text {th }}$ century through his idea of methodological nominalism (or methodological individualism). Thus it is also possible to follow the Methodenstreit along the lines of methodological individualism-methodological holism. The proponents of methodological individualism believe that societies as real entities do not exist, and that only individuals exist. If one is to understand a society, nation, class or other collectivity, one must start from studying the individuals that constitute it. A people, for example, cannot have a will which is independent of the individuals comprising it, thus if we are to understand a specific 
people and the happenings within, we must first study the individuals that constitute it. There is nothing outside of individuals, and societies and similar collectivities do not have their own separate self which can be understood regardless of its parts. This standpoint was later adopted, among others, by Ludwig von Mises and Carl Popper (Kulenović 2014). These authors proposed that methodological individualism was the only path towards the emancipation of social sciences from abstract metaphysical and mystic totalities. From this perspective, the historistic affirmation of understanding methods compromises the scientific principle of social sciences and reduces them to arbitrary relativistic considerations.

Yet another level of the dispute over methods was situated on the demarcation line between explanation and understanding. ${ }^{1}$ The authors that advocated the strict scientific characters of social sciences and adopted the standpoint of methodological monism, believed that the aim of all scientific research is to explain. Scientific explanation is an epistemological category which derives individual phenomena from general theoretical tenets. The main instruments of scientific explanation are scientific theories and scientific laws, and they are all applicable to the field of social, cultural and historical research. Contrary to that, the application of understanding methods assumes that social phenomena are impossible to explain using these general theoretical tenets in the same way as nature is explained. Therefore, these authors strive for the understanding of the sense and meaning of a phenomenon in a wider historical context. ${ }^{2}$ This is what led to the appearance of hermeneutics, which marked an abrupt cessation of the traditional methods of explaining social and cultural phenomena. Through understanding, as the sociologist Đuro Šušnjić writes, one emphasizes the dominance of method over subject. This procedure was first applied by Friedrich Schleiermacher, who presented hermeneutics as a theory which deals with the conditions of understanding, that is, the meanings that certain phenomena hold for us, and not with the search for the causes of these phenomena, which is deemed characteristic of the external, objectivist method (Šušnjić 2015, 117).

\section{Certain ASPECTS of the Dispute AND tHE REAFFIRMATION OF HERMENEUTICS}

If we are to travel back to the very beginning of the dispute, the starting point should be sought in the different understanding of the economic science by Carl Menger and Gustav von Schmoller, the representatives of the Austrian and German school, respectively. These two authors debated in their writings, books and articles, with Schmoller taking the position that corresponded to the historicistic understanding of the method. He believed that it was impossible to discover universal economic laws, i.e. laws on a global level. However, one could determine through observation and empirical research the concrete economic laws of a given society in a given epoch. For this reason, it is clear that deduction was not an acceptable method for Schmoller. Instead, Schmoller and the other authors of the German historical school conducted extensive research into certain economic phenomena of German cities and states. The story goes that they assigned specific research topics to students that

\footnotetext{
${ }^{1}$ More about the explanation in social sciences in Nejgel 1974, 447.

${ }^{2}$ However, among the proponents of understanding there are certain disagreements on what understanding exactly relates to. While one group was more prone to the psychologistic, intuitionistic take on this method, attributing emotional involvement to it and applying it to collective forms of social life, the other group saw understanding as a process of discovering the motives of an individual (and not the collective), thus being closer to the (already mentioned) methodological individualism.
} 
dealt with particular regions, i.e. the cities from which those students originally came. They believed that is was necessary to choose a specific space and a specific problem that would be investigated in more detail in that space. This, however, did not mean that such a problem was to be generalized as a universal economic law. Today, when scrutinizing the contribution of their vast research, it is believed that these authors managed to accumulate enormous material, but did not actually improve economic science (Stojanović 2008, 18). Contrary to Schmoller, Menger believed that one should start from the general theories that would in turn be applied to an actual series of cases, yet he also believed that when studying economic phenomena a researcher had to begin with concrete individuals. As a follower of methodological individualism, he believed that general assumptions could not be grounded unless they rested on individual thriving (Menger, 2008). Because of this, his opposition blamed him for Mill's atomism and subjectivism.

This was just the beginning of the dispute that would continue with a number of approaches, with historism taking off in the second half of the $19^{\text {th }}$ century led by different authors. Two Neo-Kantian philosophers, a teacher and a student, should be mentioned as the most significant: Wilhelm Windelband and Heinrich Rickert. Windelband's rector's lecture, which can, in a way, be considered a manifesto of historism, represents an important source for understanding this methodological approach. "History and Natural Science" is the title of the lecture given in Strasbourg in 1894, where Windelband presented his account of two types of sciences that differ in their subject and method. These are nomothetic and idiographic sciences. The former study nature and their goal is to find the causes and determine the laws, while the latter are directed towards the individual, the unrepeatable and the unique. Therefore, idiographic sciences describe social, historical and cultural phenomena in detail. The difference in the aims of the sciences stems from the different research subjects, while the essence lies in the different quality of knowledge: the knowledge of society is not theoretical, as is the case with natural sciences, but historical, with the flow of history being fragmentary, marked with discontinuity, and that is why it is impossible to find laws within it. ${ }^{3}$ Rickert followed Windelband, with certain minor deviations and a slightly different dichotomy of sciences. ${ }^{4}$ What was particularly problematized by this author was the problem of values, that is, how it was possible to avoid their excessive influence on a researcher of cultural phenomena. That is why he advocated the creation of a universal system of values that would enjoy consensus and serve as the basis for problem selection. When studying extraordinary individuals and their lives in history, Rickert believed we do not have to agree on whether they played a positive or negative historical role; however, we have to agree on them marking a particular historical era, thus qualifying themselves as an inevitable research subject in cultural sciences (Staiti 2013).

\footnotetext{
${ }^{3}$ Later on Arnold Hauser would also write on the difference between natural and historical phenomena. According to him, the development of nature mainly experiences the development of constant and permanent characteristics, strengths and tendencies, while history contains unpredictable variations of relevant motives. Furthermore, cultural and social factors, contrary to natural ones, act together in the historical process as "tenets of mobility and dynamics". As entities conditioned by a certain situation, such as the position, class, community of interest, layers of education, social circles and the like, cultural and social factors are subject to constant development, differentiation and integration. Hauser particularly emphasizes the fact that not one of these structures remains unchanged for a longer period, regardless of how stable the circumstances. "The natural data remain essentially stable in spite of their changing function and the different use made of them; they do not appear as purely natural phenomena on the historical level. On the other hand, the cultural factors in the historical process are essentially dynamic, lively, and mobile" (see Hauser 1986, 118-119). The research in this context continues to this day.

${ }^{4}$ Rickert divides sciences into natural sciences and cultural sciences. While natural sciences are devoid of value judgments, cultural sciences are determined by values, since culture itself is a field shaped by values.
} 
To summarize, the above authors believed that there is a fundamental difference between social and natural movements and that, therefore, the methods of the sciences that study them need to be different as well. As a separate current within the Methodenstreit which stemmed from such observations, hermeneutics appeared led by the protagonist Wilhelm Dilthey. In his so-called philosophy of life (Lebensphilosophie), Dilthey states that life precedes notion, and thus he confronts Kant's apriorism and the Neo-Kantian philosophers Windelband and Rickert (representatives of the Baden or "value-theoretical" school). According to Dilthey, a human life can be understood exclusively from within, which led to him being criticized for reductionism, i.e. the reduction of spiritual sciences to psychological ones. However, Dilthey's philosophical concept also rests on social sciences. That is why his entire epistemology and methodology of social sciences has to be observed in a wider context of the construction of spiritual sciences, based on the fundamental (ontological) difference between natural and social sciences. He understood the difference in the subject matter of these two scientific groups, which prevents one from postulating a single generally relevant scientific conceptual system (Diltaj 1980b, 139).

The discrepancy between natural sciences (Naturwissenschaften) and spiritual, cultural sciences (humanities) (Geisteswissenschaften) was emphasized during the dispute over methods. The final outcome of this dispute, i.e. battle, can be presented as a path that leads from understanding humans as natural beings to studying them as spiritual (cultural) beings. According to Dilthey, there is a great difference between the methods used to study spiritual life, history and society, on the one hand, and the methods applied in the examination of natural phenomena, on the other (Diltaj 1980b, 54). It was crystal clear to him that the knowledge of society is far less accurate than the knowledge of nature, yet it possesses the advantage of not being phenomenal but based on direct experience and understanding (Milić 1978, 142).

Šušnjić has created a systematic image of these differences using a simplified overview of the sciences that explain and the sciences that understand.

Natural sciences
Explanation
Cause, condition, background
Facts
Sensory (a thing)
Event
Man as a natural unit
Man as a passive object
Society (Gesellschaft)
Rational knowledge
Common nominator
General norm
Theory of knowledge
Observation
External
Scientific law
Physical
Natural science

Natural sciences

Cause, condition, background

Facts

Event

Man as a natural unit

Man as a passive object

General norm

Theory of knowledge

Observation

External

Physical

Natural science

\author{
Spiritual sciences \\ Understanding \\ Motive, reason, intention \\ Meaning of facts, interpretation \\ Suprasensory (above a thing) \\ Experience \\ Man as a personality \\ Man as an active subject \\ Community (Gemeinschaft) \\ Abundance of life \\ Historically individual \\ Individual experience \\ Psychology of knowledge \\ Involvement, intuition \\ Internal \\ Idiographic description of a living assembly \\ Psychological \\ Hermeneutics (science about meaning)
}

(Šušnjić 2015, 118). 
There are many kinds of hermeneutics (Greek hermeneutike - express, translate). Maria Janion first mentions the ancient Greek hermeneutics, followed by the Jewish, medieval, humanistic hermeneutics of the Renaissance, Protestant, Romantic and Dilthey's so-called comprehensive hermeneutics (Janjion 1976, 151). Hermeneutics is most commonly associated with the interpretation of sacred scriptures, above all the Bible; however, both before and after Christianity, this interpretation procedure was applied to various other areas, such as arts and history. Hermeneutics as a method comes to life in those moments in history when the existing tradition loses sense, provides no answers and requires new interpretation: "Hermeneutics is the art and science of reading the tradition, that is the world" (Janjion 1976, 152). Moreover, hermeneutics does not only aim to understand something, but also to bring it closer to people, to make it understandable for them, to discover that which is hidden. This is further corroborated by Dilthey in his lucid observation: "The ultimate goal of the hermeneutic process is to understand the author better than he understood himself' (Diltaj 1980b, 109). This process is applied to discover the meaning of texts, i.e. messages. Every message is symbolic and contains more than one meaning - it can be understood in various ways. Dilthey once said: "The hermeneutic science is the teaching of the skill of interpreting written monuments" (Diltaj 1980a, 97). According to him, all of that in which the spirit is objectified belongs to the field of spiritual sciences, and these spiritual sciences are cultural sciences. His final point is made: "We explain nature, but understand spiritual life." To understand spiritual life we must approach it from within, which is not the case with natural phenomena. When it comes to natural phenomena, what is important are the external links, and their explanation is possible by determining the cause and effect relation. The basic methods in the research into social reality (culture, spirit) are understanding and interpretation. In short, we must first get involved in the given phenomena or behaviours, then understand the behavioural motives of the given agents in specific activities, and finally provide an explication, i.e. interpretation of the phenomenon in question. This is the path that was also taken by Max Weber's sociology of understanding (Verstehende Soziologie).

Understanding as the main form of experience objectification represents a way to connect separate events into a larger meaningful whole. Anthropologically speaking, according to Dilthey, it is also possible to understand (enjoy) other people's experiences, and it is interesting to note that he believed that for a human being even nature only exists indirectly through one's experience interwoven with meaning, value and purpose (Diltaj 1980a, 151). This "philosopher of life" calls the full scientific understanding of historical wholes presentation or interpretation, which is to a large extent endorsed by the personal traits of the interpreter, such as their gifts or, even, genius. Here one can observe the similarity between the method of understanding and the act of artistic creation. What is also emphasized is the importance of hermeneutics and the hermeneutic method. On the basis of the sameness of the human nature, he implied the possibility of getting involved in the life of the creator of a work of art. The basic process in this theoretical context is called the hermeneutic circle, which implies confronting the elements of an interpreted work with the work as a whole (Milić 1978, 146).

When it comes to spiritual sciences, Dilthey points out that in them, contrary to natural sciences, there is no uniformity or monolithism, but only that which is unrepeatable, singular, individual and unique. The scope of the notion of spiritual science is as wide as that of understanding, and its subject matter is everything on which humans left their mark, their spiritual trace through their activity. While nature encompasses the reality created independently of the actions of the spirit, the spirit only understands that which it 
created itself (Diltaj 1980b, 193). It is important to note that this author observed the notions of the human and the spiritual in the context of the historical life in which human beings are only beginning to express themselves as spiritual beings. Furthermore: the nature of spiritual beings relates to all types of knowledge, starting from the knowledge of reality and determination of values to the determination of purposes and rulemaking (Diltaj 1980a, 75). Judging by their scope, research subject and methodology, one could say that spiritual sciences are an adequate terminological alternation for cultural sciences. These sciences deal with people, their interrelations, relations towards nature and one another. They are grounded together in experience, regardless of it being the case of history, political economics, legal sciences, religion, literature, arts, music or psychological processes. All of them operate in abstractions and not entities within the domain of their research.

Dilthey's research left no one indifferent, even including later philosophers (as well as cultural historians, cultural sociologists, psychologists and other scientists). Thus, Heidegger recognizes that in Dilthey's constitution of spiritual sciences a human being is not observed as an object of consideration (a natural thing constructed from other general laws of events) but is understood as a living person with a history of actions (Ružić i Božilović 2016, 243). What is key in Dilthey's research is not only the establishment of a theory of spiritual sciences but above all a tendency to observe the historical reality and discover the possibilities of conceptual interpretation. Contrary to naturalistic psychology, Dilthey started the personalistic discourse in which "that psychological aspect" was no longer to be understood as a natural event, but as spirit and person (Ružić i Božilović 2016, 247). Pointing to the importance of the notion of life, which constitutes the basis of our existence, Wilhelm Dilthey, along with Johann Gottlieb Fichte, greatly contributed to the psychology of knowledge - a cornerstone in the hermeneutics of theoretical results of all forms of research. When speaking of psychology, it is necessary to emphasize that Dilthey abandoned the idea of psychology as the basis of all "spiritual" sciences. This is related to the re-examination and assessment of the scientific importance of biography and autobiography. For Vojin Milić, there is a certain confusion in Dilthey after all, particularly in the sense of insufficient definition and vagueness of some of the key categories, among which are experience, understanding and structure (Milić 1978, 139).

Dilthey's epistemological-methodological approach was criticized on other bases as well. His critics objected to a lack of elaboration in his system, even instances of logical inconsistency. Milić's remark relates to Dilthey's idea of history as a single general science about society being undeveloped in the logical sense. Subjectivism makes this concept also ungrounded in that Dilthey brings history very close to art. Particularly moot are the ideas of historism on the impossibility of the theoretical knowledge of society, as well as Dilthey's unproven statements on the futility and adversity of sociology (see Milić 1978, 149). In addition, what is present is the hypertrophy of the elements of the "psychological structural assembly" - experience, sensory observation, desire, intuition and others. The general remark made by the critics can be summarized in a single sentence: The entire content of social life cannot be positioned within one's "internal" experience, while utterly disregarding "external" influences. 


\section{IDEOLOGICAL BACKGROUND OF THE DISPUTE: HISTORISM AND ROMANTICISM}

No science appears and develops independently of the social context and the happenings surrounding it, and this can also be observed in the example of the constitution of social sciences in the $19^{\text {th }}$ century. Positivism and its related standpoints found their stronghold in the social atmosphere driven by the Enlightenment values, as well as advanced industrialization. It was believed that society was finally emancipated from the theological medieval dogmatism and that it moved unhindered, progressively towards higher stages of development, in an evolutionary manner. Positivists rejected every form of previously determined history, not just theological metaphysics. It was necessary to emancipate social thought from all unscientific, philosophical doctrines. Great philosophical systems that spoke of the end of history and its purposefulness had an equally adverse effect on society as theological dogmas did. Therefore, Hegel's and Marx's thinking was criticized. Even though positivism, similarly to Hegel's and Marx's theory, strived for the discovery of laws, the two were eventually conflicted, since it was a case of a different type of laws. The predictability of the flow of history in these two authors stemmed from necessity, yet it was closer to the teleological type of explanation (similar to the antipositivist school), and not the causal one, advocated as the only possible scientific solution by the Galilean (positivist) tradition. Popper would criticize such currents of thought in The Poverty of Historicism naming them historicism. ${ }^{5}$

Popper's advocacy of methodological individualism is connected to his own liberal aspirations. His goal was the emancipation of science from pseudoscience, as well as from all related methodological holisms, which use arbitrary methods to explain the sociohistorical development and thus affirm the repressive, antiliberal, totalitarian ideological systems. By presenting historical development as a natural process, they create the impression that everything is predetermined and that people cannot change things through their activities, but only by participating in them passively. Such an interpretation of social development possesses a mythical character. Reconciliation with the predetermined reality eliminates all human activity and turns people into powerless historical figures. Popper believed that the victory of the scientific principle over the pseudoscientific one would lead to the victory of the idea of freedom in society. He also believed in the existence of a common scientific method, relevant for both natural and social sciences. Popper's methodological monism is grounded in the idea that both sciences study empirical objects, which cannot be collectivities but only individuals as their elements. However, psychologism is also not acceptable. The reduction of social phenomena to psychological phenomena is a form of reductionism which is simply not acceptable. Instead, what is proposed is institutionalism or the principle of rationality (Kulenović 2014, 319; Brdar 2008).

\footnotetext{
${ }^{5}$ It should be mentioned here that even though sometimes used interchangeably in the same sense, historism and historicism differ as methodological approaches in the context of the Methodenstreit, and that one should differentiate between the two terms. The primary reference here should be Popper (2009) who when criticizing historicism assumes that it implies that prediction is possible in history and that social sciences should discover laws and the future in the flow of history (more on this in Popper 2009). Historism, on the other hand, relates to the school of thought established in Germany at the end of the $19^{\text {th }}$ century, whose protagonists believed that the research methods of natural and social sciences had to differ, since the subject matter of the former was nature, and the subject matter of the latter spirit, i.e. culture. The difference between historicism and historism is sometimes interpreted in the manner that both of them are called historisms, where the variant of historism that searches for the historical laws is called nomothetic historism, while the study of individuals as historical units is called idiographic historism (Janjion 1976, 135). The former would be analogous to historicism, while the latter would imply historism in the sense assigned to it in this paper.
} 
While Western Europe developed its culture on rationality, Germany answered with Romanticism and historism, which Meinecke calls the greatest revolutions in German thought since the Reformation (Janjion 1976, 137). Even though the Romantic concept of the world is not exclusively related to Germany, nor to a specific century, nevertheless it was most present in this European country during the $19^{\text {th }}$ century, affecting its entire spiritual and social life. The rise of this movement is linked to the period from 1790 and 1850, when it spread from Germany to England, and later to France, Russia and other countries. It was most expressed in arts, above all, in literature, music and painting, colouring their contents with melancholic fervour. Romanticism championed irrationality, the force of spirit, the rule of emotions and passion, thus the object of admiration was an individual of extraordinary ability and charisma, a genius and a hero. Destinies of renowned historical figures were studied, and death was celebrated as their heroic end. The scope of the Romantic understanding of reality was perhaps best determined by Baudelaire in saying that Romanticism is the same sentiment about the world, and not a common notional standpoint, from which one can draw a conclusion that the mid-point of Romanticism was in the emotions, and not in the reason. When describing Romanticism Novalis says: "By giving a higher meaning to the general, a mystical appearance to the common, the dignity of the unknown to the known, the glow of the infinite to the finite, I romanticize it" (Zafranski 2011, 6). Zafranski adds to this: "The Romantic spirit is multiform, musical, experimental and tempting, it likes distance, the future and the past, surprises in the everyday, extremes, the unconscious, dreams, madness, labyrinths, reflection. The Romantic spirit does not remain the same, it is changeable and contradictory, yearning and cynical, infatuated with the unintelligible and the folk, ironic and dreamy, in love with itself, social, aware of the form and getting rid of the form. The old Goethe (Johan Wolfgang Goethe) said that the Romantic was sick" (Zafranski 2011, 7).

In the philosophical sense, Romanticism appeared as an opponent to the great philosophical systems grounded in German idealism. Furthermore, Romanticism resisted the Enlightenment and all theories of social contract that founded the state on agreement and strict rationality. The bureaucratization of society was also rejected, since it was deemed adverse to the importance of the direct relationships between people. The vision of a Romantic community was pastoral, based on the relationships of solidarity and patriotism. ${ }^{6} \mathrm{~A}$ community opposes the society dominated by rational and cold relations, and this dichotomy was best described in the work of the German sociologist Ferdinand Tönnies Community and Society. A community (Gemeinschaft) is characterized by the natural connectedness of people, solidarity, mutual trust, direct relations, tradition and customs. On the other hand, a society (Gesellschaft) is marked by relations of calculation, selfishness and egotism, where reason dominates over emotions (Tenis 1987).

The historistic understanding of history and society cannot be comprehended if separated from Romanticism. The opposition towards scientific strictness, the understanding of society as a machine and the understanding of culture as something dynamic, alive and unpredictable, are the common properties of Romanticism and historism. ${ }^{7}$ Furthermore, Romanticism

\footnotetext{
${ }^{6}$ Romantic ideas would contribute to the rise of nationalism in Europe. Also, the fascist ideology would be inspired by certain Romantic concepts, although they would be brought to extreme, banalized, distorted and abused.

${ }^{7}$ Johann Gottfried von Herder is an unavoidable figure in the consideration of Romanticism in the philosophical thought, and this author also expressed realizations in line with the historicistic view of social sciences. He placed emotions above reason and criticized the Enlightenment, causing Kant to object to his arbitrariness and inaccuracy in
} 
reflects on historism in that it understands history as a fragment, and not a meaningful and purposeful linear sequence. The most conspicuous link between the two movements is the elevation of the individual as a historically important figure who can change a given era. In line with this, historists believe that the study of remarkable individuals, as important historical figures, is the adequate way of gaining the knowledge of the meaning of the era in question. Through influential individuals, their lives and their works, one can understand the context of an entire era of which they were a part and which they marked in a certain way. In that sense, it is important to mention the German historian and antipositivist Johann Gustav Droysen, a man who in his work on Alexander the Great ${ }^{8}$ established the German historistic school. Apart from applying the historistic method in his research, this author was also significant because he introduced the dichotomy of explanation (Erklären) and understanding (Verstehen), which would later turn out to be one of the key points of the two sides in the dispute.

Let us digress here for a second. It can be considered that cultural history was constituted on these epistemological foundations (as a historical, but also cultural discipline). The period between 1800 and 1950 was named the era of "classical" cultural history by Peter Burke, and this author considered the Swiss historian Jacob Burckhardt and the Dutch historian Johan Huizinga as the classics of the era. Cultural historians focus on the history of the classic works (masterpieces of painting, literature, philosophy, science, etc.). They write their books with the intention of elucidating certain works by positioning them within an adequate historical context. Considering this approach, Burke says that cultural historians differed from the historians of art and literature in that they discussed the whole more than the parts, dealing with the relation between different arts towards that which was, in keeping with Hegel and other philosophers, often called "the spirit of the time" or Zeitgeist.

The above said presents an excellent example of how new scientific disciplines are born thanks to the research in the field of methodology. In the given case, the following is also interesting: the German historians of that era used to say that they dealt with the Geistesgeschichte. This term is often translated as "the history of the spirit" or "the history of the mind", however, the most suitable counterpart would probably be "the history of culture" (see Berk 2010, 12-13).

\section{CONCLUDING REMARKS}

The Methodenstreit turned out to be a complicated story that cannot be observed exclusively as a dichotomy, taking into account that within this dispute that started in the $19^{\text {th }}$ and lasted throughout the entire $20^{\text {th }}$ century we had a number of authors who occupied positions that took something from both movements, while opposing them in some other aspects at the same time. The authors that traverse the middle of the road are Max Weber and Georg Henrik von Wright, since for them explanation and understanding

deduction. Herder replied that there were no a priori notions and that knowledge was experiential in origin (Milosavljević 2008, 227). According to this author, the study of the historical development does not rest upon strict laws understood in the rationalistic sense that correspond to nature, but rather upon the progress that stems from the particularity of people as social and cultural beings. Thus the history of humanity cannot be understood unless one takes into account the social and cultural aspects of the human beings, their values and emotions, and not only their reason

8 "Geschichte Alexanders des Grossen" (Hamburg: Perthes, 1833). 
were not mutually exclusive as methods but, in fact, complimentary. Von Wright, therefore, takes the standpoint of methodological parallelism, as observed by Mihailo Marković. Even though he admits that natural sciences and humanities have subjects that are different in their "nature", von Wright believes that there is determinism in both of them, although of a different kind. Natural determinism comes from the unchangeable regularity, while in social sciences it is connected to motivation and intention. The fact that spiritual sciences, as Dilthey calls them, operate with creations different from the natural ones, does not mean that they cannot be subjected to certain laws and examinations. However, von Wright emphasizes that not all social phenomena are equally liable to prediction. Those human behaviours that are mechanical, prone to routine, can be studied and predicted more easily. This is usually the case with the situations that occur through manipulation and are caused by fear (e.g. the behaviour of people in a political manifestation in a totalitarian regime). These behaviours can be monitored almost in the same manner as natural phenomena are. However, the other extreme is a certain historical situation that cannot be subjected to any rules, which is sudden and difficult to explain and understand. Those are the moments that change history and the established social patterns. Between these extremes lies a number of other social phenomena that are available to social researchers to a greater or lesser degree (Marković 1975, 19).

As far as sociology is concerned, historism left a deep mark on almost all German sociologists. Even though neither Rickert not Dilthey saw sociology as the ultimate social science, through their work they both indirectly influenced the development of the sociological method by inspiring Weber and other German sociologists with their ideas. The comprehensive sociology of Weber is based on Dilthey's understanding of the aim of spiritual scientific research, while Rickert's teaching on cultural sciences positioned Weber on the side of sociologists who consider values and subjective meanings inevitable in the understanding of society. Georg Simmel, another German sociologist, speaks in particular about the importance of understanding in social sciences, connecting it with psychology. He believes that understanding is a form of empathy, which can be enriched by a researcher's imagination, employed to create a spiritual atmosphere of a certain time being studied. Apart from being imbued with empathy, understanding is also founded on the intentionality comprised of intents and aims of the one who acts (von Wright 1975: 60). He writes about history being a mess of material that cannot be cleared up by the approach proposed by historism. A researcher uses their spiritual activity to order and conceptualize historical events constituting a meaningful whole. A historian is a creator, and the knowledge of history is not a passive reproduction, but a meaningful interpretation (Janjion 1976, 169). In the spirit of historism, Simmel believes that nature and society differ essentially, since the elements in nature are bounded by general laws, which is something that is not found in society. A society is made up of individuals, thus it cannot be understood without them. It is not superindividual, as it was for Durkheim. In that sense, Simmel adopts the same standpoint of methodological individualism (nominalism) as Mill did. ${ }^{9}$ An individual is a person who is unique and he or

\footnotetext{
${ }^{9}$ Simmel says: "This reciprocal activity means that the individual bearers of these impetuses and aims form a unity, that is, "a society". Unity in the empirical sense is nothing but reciprocity of elements: an organic body is a unity because its organs are in a more intimate interchange of energies with one another than with any outside agent, and the state is a unity because between its citizens there is a more intimate exchange of reciprocal influences, while we could not call the world a unity unless each one of its parts somehow influenced every other one, or if this reciprocity of influences was severed somewhere" (Zimel 1987, 249).
} 
she cannot overlap with the other individuals that constitute a society. Therefore, Simmel believes that it is not possible to find laws within a society in the same manner as one could in natural sciences with their subject matter. The part of an individual that is unrepeatable does not belong to the social category, and it is possible to study it only from the standpoint of history and psychology, while the role of sociology is to abstract that which is common to all and construct a meaningful whole by studying that content.

In any case, the $19^{\text {th }}$ century was marked by the conflicts between the positivist and antipositivist currents, and this battle spread to all social sciences, which, as von Wright says, became the battlefield for the belligerent movements in the philosophy of science (von Wright 1975, 60). Since the arguments of both sides were strong, it seems that modern sociology has only benefitted from this dispute, because both positivist and historistic views were successfully implemented into its method during the decades of its development. In certain periods the positivist current of social thinkers was the dominant one, while the other periods were marked by those authors who observed culture in a manner much more complex than the one provided by mere statistics. The heritage of this dispute can, therefore, be witnessed in the abundance of sociological approaches and methods that sociology possesses today.

Acknowledgement: The paper is a part of the research done within the project Tradition, Modernization and National Identity in Serbia and the Balkans in the European Integration Process (179074), financed by the Ministry of Science and Technological Development of the Republic of Serbia and implemented by the Centre for Sociological Research at the Faculty of Philosophy, University of Niš.

\section{REFERENCES}

Berk, Piter. Osnovi kulturne istorije. Beograd: Clio, 2010.

Brdar, Milan. Pouke skromnosti: Karl Poper, otvoreno društvo, nauka i filozofija. Beograd: Zavod za udžbenike, 2008.

Diltaj, Vilhelm. Izgradnja istorijskog sveta u duhovnim naukama. Beograd: BIGZ, 1980a.

Diltaj, Vilhelm. Zasnivanje duhovnih nauka. Beograd: Prosveta, 1980b.

Hauser, Arnold. Sociologija umjetnosti, tom 1. Zagreb: Školska knjiga, 1986.

Janjion, Maria. Romantizam, revolucija, marskizam. Beograd: Nolit, 1976.

Kulenović, Nina. „Metodološki individualizam nasuprot metodološkom holizmu“. Etnoantropološki problemi 9,2 (2014): 309-333.

Menger, Karl. Istraživanja o metodi društvenih nauka s posebnim osvrtom na političku ekonomiju. Beograd: Službeni glasnik, 2008.

Milić, Vojin. Sociološki metod. Beograd: Nolit, 1978.

Milosavljević, Ljubinko. Podsticanje slobode. Niš: Filozofski fakultet, 2008.

Nejgel, Ernest. Struktura nauke. Beograd: Nolit, 1974.

Poper, Karl. Beda istoricizma. Beograd: Dereta, 2009.

Ružić, Goran i Jelena Božilović. "Hajdegerovo tumačenje pojma istorije kod Vilhelma Diltaja i Jorka fon Vartenburga". U Istorija ideja i promišljanje savremenog sveta, uredila. G. Stojić, 243-259. Niš: Filozofski fakultet u Nišu, 2016.

Staiti, Andrea. "Heinrich Rickert". In Stanford Encyclopedia of Philosophy, edited by Edward N. Zalta. Stanford University: Center for the Study of Language and Information, 2013. Available at: http://plato.stanford.edu/ entries/heinrich-rickert/.

Stojanović, Božo. „Karl Menger i austrijska škola“. U Karl Menger, Istraživanja o metodi društvenih nauka, s posebnim osvrtom na političku ekonomiju, 1-25. Beograd: Službeni glasnik, 2008.

Šušnić, Đuro. Teorije kulture: predavanja. Beograd: Zavod za udžbenike, 2015.

Tenis, Ferdinand. „Zajednica i društvo“. U Formalizam u sociologiji, uredio Radomir Lukić, 235-241. Zagreb: Naprijed, 1987. 
Von Wright, Georg Henrick. Objašnjenje i razumevanje. Beograd: Nolit, 1975.

Windelband, Wilhelm. „History and Natural Science“. History and Theory 19, 2 (1980): 169-185.

Zafranski, Ridiger. Romantizam: jedna nemačka afera. Novi Sad: Adresa, 2011.

Zimel, Georg. „Sociologija“. U Formalizam u sociologiji, uredio Radomir Lukić, 247-260. Zagreb: Naprijed, 1987.

\section{ANTINOMIJE METODA ISTRAŽIVANJA U DRUŠTVENIM NAUKAMA: SPOR OKO METODA}

Centralno pitanje ovoga rada je takozvani spor o metodu (Methodenstreit), koji je zasnovan na suštinskom razlikovanju prirodnih i društvenih pojava. Metodološka pitanja u sociologiji vezana su za utvrđivanje njenog predmeta $i$ u istoriji ove nauke ona su predstavljala čvorno mesto neslaganja među teoretičarima. Debate koje se tiču pitanja prirodnih i društvenih pojava $i$, u vezi sa tim, načina njihovog proučavanja, započinju još iz vremena antičke filozofije - od Aristotela i produžavaju se preko tzv. Galilejevske struje koja će vrhuniti u pozitivističkom pravcu i njemu suprostavljene istorističke škole. U radu se ukazuje na teorijsko-metodološke pozicije obe struje u sporu, na reafirmaciju heremenutike, kao i na njihovu ideološku zaleđinu, ali se čini osvrt i na neka shvatanja koja su se formirala integrisanjem ideja obe metodološke struje.Vreme spora oko metoda je doba konstituisanja sociologije, pa se u zaključnom razmatranju ističe značaj ovog sukoba za konstituisanje sociologije kao nauke, sa posebnim osvrtom na uticaj istorizma na nemačke sociologe.

Ključne reči: istorizam, hermeneutika, pozitivizam, romantizam, sociologija. 